\title{
Unusual Cyan-Purple Electrochromism of Sandwich Phthalocyaninates Observed on the Example of $\mu$-Carbido Diruthenium(IV) Complex
}

\author{
Daria S. Kutsybala, ${ }^{a}$ Alexander V. Shokurov, ${ }^{a @ ~ A n d r e y ~ P . ~ K r o i t o r, ~}{ }^{a}$ \\ Alexander G. Martynov, ${ }^{a}$ Sofia L. Selektor, ${ }^{a}$ Aslan Yu.Tsivadze, ${ }^{\mathrm{a}, \mathrm{b}}$ \\ and Yulia G. Gorbunova ${ }^{a, b}$
}

\begin{abstract}
a.N. Frumkin Institute of Physical Chemistry and Electrochemistry of Russian Academy of Sciences, 119071 Moscow Russia ${ }^{\mathrm{b}}$ N.S. Kurnakov Institute of General and Inorganic Chemistry of Russian Academy of Sciences, 119071 Moscow, Russia

${ }^{\circledR}$ Corresponding authorE-mail: shokurov@phyche.ac.ru
\end{abstract}

Dedicated to the memory of Prof. Larisa G. Tomilova

\begin{abstract}
Current research in sandwich phthalocyaninates enjoys increasing interest due to peculiar properties of these compounds, i.e. their intense coloration and ability to change and control it via redox processes. Obviously, such effect found its application in development of electrochromic devices. In the case of commonly studied rare earth element bisphthalocyaninates, the most dominant electrochromic palette observed for them lies within the red-green-blue gamut. In this work, we report that an unusual sandwich - covalently-bridged $\mu$-carbido diruthenium(IV) bisphthalocyaninate - exhibits equally unusual color changes upon its reversible electrochemical oxidation/reduction, namely switching from cyan to purple. The study provides a detailed spectroelectrochemical characterization of this $\mu$-carbido-dimeric complex in solution, in thin cast and ultrathin Langmuir-Schaefer films, which all demonstrate aforementioned variable vibrant coloration in action.
\end{abstract}

Keywords: Phthalocyanine, sandwich complex, electrochromism, ruthenium, Langmuir-Shaefer film.

\section{Необычный фиолетово-голубой электрохромизм сэндвичевых комплексов на примере бисфталоцианината $\mu$-карбидо- Аирутения(IV)}

\author{
А. С. Куцыбала, ${ }^{a}$ А. В. Шокуров, ${ }^{a}$ А. П. Кройтор, ${ }^{a}$ А. Г. Мартынов, ${ }^{a}$ \\ С. А. Селектор, ${ }^{a}$ А. Ю. Цивадзе, ${ }^{a, b}$ Ю. Г. Горбунова ${ }^{a, b}$
}

${ }^{a}$ Институт физической химии и электрохимии им. А.Н. Фрумкина РАН, 119071 Москва, Российская Федерация ' Институт общей и неорганической химии им. Н.С. Несмеянова РАН, 119071 Москва, Российская Федерация

${ }^{\circledR}$ E-mail: shokurov@phyche.ac.ru

Посвящается памяти проф. А. Г. Томиловой

\begin{abstract}
Современные исследования в области сэндвичевых фталоцианинатов вызывают все больший интерес в связи с особыми свойствами этих соединений, такими как, например, их интенсивная окраска и возможность управления её изменениями с помощью окислительно-восстановительных процессов. Такие эффекты находят применение при разработке электрохромных устройств. В случае наиболее изученных бисфталоцианинатов редкоземельных элементов доминирующая электрохромная палитра таких соединений лежит в красно-зеленосиней цветовой гамме. В данной работе показано, что такой необычный сэндвич, как ковалентно-связанный бисфталочианинат н-карбидо-дирутения, при обратимом электрохимическом окислении/восстановлении
\end{abstract}


проявляет необычные изменения окраски, а именно - переход от голубого цввета к фиолетовому. Проведённые исследования включают детальную спектроэлектрохимическую характеризацию этого комплекса в растворе, в тонких пленках хаотической организачии и ультратонких пленках Ленгмюра-Шефера, которые в действии демонстрируют вышеупомянутое яркое быстрое и обратимое изменение иявета.

Ключевые слова: Фталоцианины, сэндвичевые комплексы, электрохромизм, рутений, пленки ЛенгмюраШефера.

\section{Introduction}

The ability of rare earth element (REE) cations to form double-decker complexes with phthalocyanine ligands was first reported by I.S. Kirin and P.N. Moskalev in 1965. [1] These complexes possessed rich and intriguing electrochemical properties, so this pioneering work provided the basis for further fruitful research on phthalocyanine sandwiches and related compounds. ${ }^{[2-4]}$ Altogether, it led to important advances in discovery of new structural types of multi-decker compounds $s^{[5-7]}$ and the development of new redox-active materials, ${ }^{[8,9]}$ components of molecular memory devices, ${ }^{[10]}$ molecular switches, ${ }^{[11-13]}$ single molecule magnets, ${ }^{[14]}$ fluorescent probes, ${ }^{[15,16]}$ etc. One of the most prominent features of sandwich REE phthalocyaninates is their ability to change color within red-green-blue gamut upon Pc-centered redox-transformations, ${ }^{[17-20]}$ which made them valuable components of electrochromic materials and sensors. ${ }^{[21-24]}$

In the context of studies devoted to sandwich complexes, the legacy of Professor Larisa G. Tomilova is difficult to overestimate. Since early 1980s her research interests have been unfailingly focused on doubleand triple-decker complexes involving their thorough characterization and fabrication of materials and devices via thin-film technologies. ${ }^{[25-29]}$ The experience and sincere interest in the studies of sandwich complexes have allowed L.G. Tomilova to create the leading world-class scientific school, ${ }^{[30]}$ where REE bis-/trisphthalocyaninates and higher sandwiches have been synthesized and both their fundamental and applied aspects were studied. Even our research is deeply intertwined with this scientific school, since Yulia Gorbunova was a post-graduate student of Professor Larisa G. Tomilova. ${ }^{[31-33]}$
The specific interest paid to sandwich complexes arises from their unique optical and electrochemical properties, which originate from efficient $\pi-\pi$ interactions between the stacked ligands. ${ }^{[34]}$ Their molecular orbitals form linear bonding and antibonding combinations, increasing the number of electronic excitations observable in UV-Vis spectra of bis- and trisphthalocyaninates in comparison to monophthalocyaninate complexes. ${ }^{[35]}$ The splitting between frontier orbitals of sandwich complexes depends on the degree of $\pi-\pi$ interactions, ${ }^{[36]}$ which in turn is governed by the size of the metal ion. Thus, the linear dependencies of the optical and electrochemical characteristics $v s$. REE ionic radii are observed, which can be used for fine tuning of electrochemical properties and adjustment of HOMO/LUMO levels via

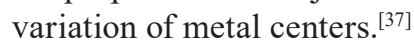

The architecture of sandwich REE complexes with Pc ligands is based on misfit between the size of the macrocyclic cavity and the large ionic radii of metal ions, while these ions can coordinate the second macrocycle due to the large coordination numbers. However, the sandwich architecture can be obtained by an alternative approach ${ }^{[38]}$ - via binding of monophthalocyaninates with nonmetal bridging atoms $[\mathrm{MPc}]_{2}(\mu-\mathrm{X})$, where $\mathrm{X}=\mathrm{C}, \mathrm{N}, \mathrm{O}$ (Figure 1a). Metal centers in such complexes include tri- and tetravalent metals like Al, $\mathrm{Mn}, \mathrm{Fe}, \mathrm{Ru}$, etc., and tetravalent metalloids like Si and Ge bearing additional anionic groups.

Largely retaining the features of the electronic structure inherent to REE sandwich complexes, $\mu$-X-bridged complexes of d-elements, especially Fe and Ru, demonstrate unique catalytic properties due to the availability of metalcentered orbitals to interaction with small molecules with the formation of reactive species. ${ }^{[39,40]}$ Although electrochemical behavior of $\mu$-X-dimers have been previously studied mainly on the examples of some $[\mathrm{PcFe}]_{2}(\mu-\mathrm{N})$
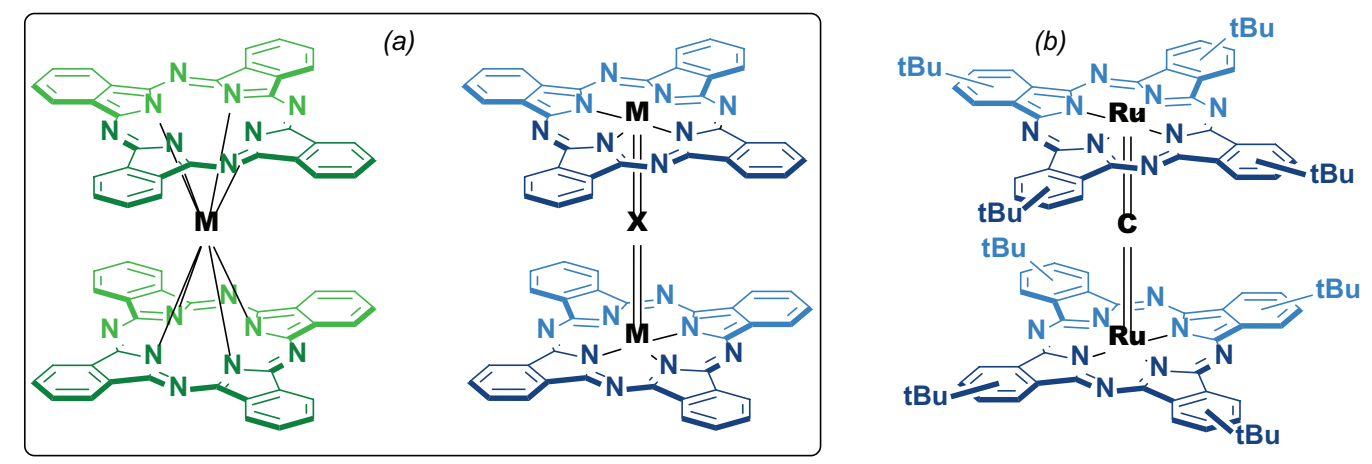

Figure 1. (a) - Comparison of double-decker architectures of REE bisphthalocyaninates and single atom bridged dimeric complexes; (b) - $\mu$-carbido-bis(tetra-tert-butylphthalocyaninato)diruthenium(IV) $\left[\mathbf{t B} \mathbf{u}_{4} \mathbf{P c R u}\right]_{2}(\boldsymbol{\mu}-\mathbf{C})$, whose spectroelectrochemistry is studied in this work. 
complexes, ${ }^{[41]}$ only scarce attention was paid to their electrochromic properties, while the ability of these complexes to coordinate various ligands can pave way to electrochemical sensing. ${ }^{[42]}$

Previous electrochemical studies of $\mu$-X-bridged dimers were mainly referred to unsubstituted compounds which could not be used to form organized thin film materials due to the lack of solubility, however, recently we reported approaches to the synthesis of substituted ruthenium(IV) $\mu$-carbido-bisphthalocyaninates. ${ }^{[40,43]}$ Thus, in the present work we report first example of the detailed spectroelectrochemical characterization of the soluble carbido-dimeric complex $\left[\mathbf{t B u}_{4} \mathbf{P c R u}\right]_{2}(\boldsymbol{\mu}-\mathbf{C})$ (Figure $1 \mathrm{~b}$ ) both in solution and in Langmuir-Schaefer films. We show that the behavior of this complex under the application of electrochemical potential is mainly similar to the one of archetypal REE bisphthalocyaninates, however, reversible oxidation/reduction of the film formed by the mentioned complex affords the switching between cyan and purple colors unavailable in the case of REE complexes.

\section{Experimental}

The complex $\left[\mathbf{t B} \mathbf{u}_{4} \mathbf{P c R u}\right]_{2}(\boldsymbol{\mu}-\mathbf{C})$ was synthesized by dimerization of the monomeric complex $\left[\mathbf{t B \mathbf { u } _ { 4 }} \mathbf{P c R u}\right](\mathbf{C O})$ upon its reaction with chloroform and $\mathrm{KOH}$ in isopropanol-toluene mixture as reported previously. ${ }^{[43]}$

UV-Vis spectra and colorimetric data were obtained using fiber optic spectroscopy setup utilizing a combination of Avantes AvaLight-DH-S balanced deuterium halogen light source and two Avantes spectrometers (AvaSpec-ULS2048CLEVO and AvaSpec-NIR256-1.7), coupled via fiber optic cables through a cell holder with co-axially positioned collimated lenses. This combination allows for detection of UV-Vis-NIR spectra in the wavelength range from 220 to $1760 \mathrm{~nm}$, however, in most cases within the present study, this range was shortened, mainly due to optical filtering of the UV light (to eliminate unnecessary photodamage of the studied dyes) and/or immense absorbance of water (when it was used as electrolyte).

Spectroelectrochemical measurements for solutions of the studied compound were carried out using a quartz-body three-electrode cell. Platinum wire acted as an auxiliary electrode; silver-chloride $(\mathrm{Ag} / \mathrm{AgCl} / \mathrm{saturated} \mathrm{KCl})$ electrode was used as a reference. Platinum mesh, placed in the optical axis of the spectrophotometric setup, was used as a working electrode. In this configuration optical path length amounted to $2 \mathrm{~mm}$. $0.1 \mathrm{M}$ dichloromethane solution of tetrabutylammonium tetrafluoroborate was used as the electrolyte for solution experiments.

Spectroelectrochemical experiments in three-electrode setup with thin films were performed using platinum petal auxiliary electrode and silver-chloride $(\mathrm{Ag} / \mathrm{AgCl} /$ saturated $\mathrm{KCl})$ reference. Glass plates coated with fluorine-doped tin oxide (FTO), onto which studied films were deposited, were employed as working electrodes. The PTFE body of the cell was equipped with coaxial quartz windows for spectroscopy measurements. In two-electrode setup, two FTO electrodes were joined together using $100 \mu \mathrm{m}$ thick double-sized tape, and the space between them was filled with electrolyte. $0.1 \mathrm{M}$ aqueous solution of $\mathrm{NaClO}_{4}$ was used as electrolyte in all the film-related experiments.

Cyclic voltammogram $(\mathrm{CV})$ measurements were performed using an "IPC-Pro" electronic potentiostat controlled by the Intelligent Potentiostat Control S2 software package ver. 8.65, both developed at IPCE RAS, Moscow, Russia. Potential sweep rate in all cyclic voltammetry experiments presented was $100 \mathrm{mV} / \mathrm{s}$.
Thin cast films (CF) of the studied complex were obtained by drop-casting from its concentrated dichloromethane solution, and roughly smoothed out during solvent evaporation using manual meniscus dragging technique.

Langmuir-Blodgett device KSV Minitrough (Finland) with PTFE trough with surface area of $273.0 \mathrm{~cm}^{2}$ and moveable barriers made of hydrophilic polyacetal was used for Langmuir monolayer formation. Compression isotherms were recorded using automated Langmuir balance and platinum Wilhelmi plate. The monolayers were formed by spreading chloroform solutions of the studied compound onto the air/water interface using a chromatographic syringe. Then the system was left undisturbed for 10-15 min in order for the solvent to evaporate from the interface. After that, monolayer compression at the rate of $5 \mathrm{~mm} \mathrm{~min}^{-1}$ commenced. Transfer of Langmuir monolayers onto solid substrates was carried by Langmuir-Schaefer technique (horizontal transfer) at surface pressure of $20 \mathrm{mN} / \mathrm{m}$. Ultrapure water $(18 \mathrm{M} \Omega \mathrm{cm})$ deionized by Millipore Milli-Q water purification system was used as a subphase in Langmuir monolayer studies.

\section{Results and Discussion}

On the first stage of the present work, electrochemical behavior of $\left[\mathbf{t B u} \mathbf{H}_{4} \mathbf{P c R u}\right]_{2}(\boldsymbol{\mu}-\mathrm{C})$ was studied in solution. Cyclic voltammogram (CV) of the compound (Figure 2), recorded in the potential range from -0.4 to $1.1 \mathrm{~V}$ (vs. $\mathrm{Ag} /$ $\mathrm{AgCl}$ electrode), shows two reversible redox peaks, corresponding to first $\left(\mathrm{ox}_{1}\right)$ and second $\left(\mathrm{ox}_{2}\right)$ oxidation of the complex. Half-wave potentials of these processes were found to be ca. 0.32 and $0.71 \mathrm{~V}$, respectively, similarly to the previously reported unsubstituted complex $[\mathbf{P c R u}]_{2}(\boldsymbol{\mu}-\mathbf{C}) \cdot{ }^{[44]}$

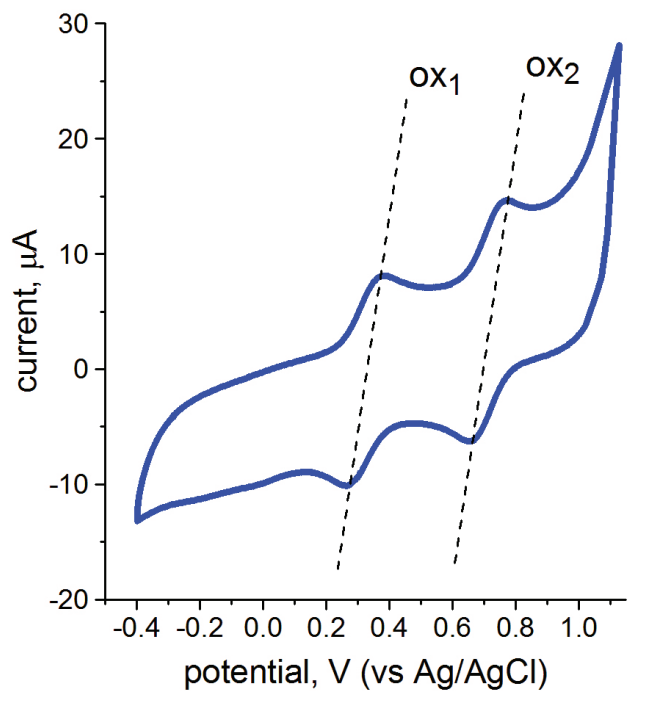

Figure 2. $\mathrm{CV}$ of $\left[\mathbf{t B u} \mathbf{u}_{4} \mathbf{P c R u}\right]_{2}(\boldsymbol{\mu}-\mathbf{C})$ in dichloromethane. Dashed lines connect marked redox peaks on anodic and cathodic branches of the CV. Only the third cycle is shown for clarity.

Spectral changes accompanying these electrochemical processes were recorded by application of 0.55 and $1.00 \mathrm{~V}$ for first and second oxidation of the complex, respectively. Corresponding spectra are presented in Figure 3.

As can be seen, the first oxidation leads to a small bathochromic shift and widening of the Q-band of the complex (Figure 3, curve 2). Such change does not cause significant 
shift of the solution color, and it remains light teal. However, after second electrochemical oxidation $\left[\mathbf{t B} \mathbf{u}_{4} \mathbf{P c R u}\right]_{2}(\boldsymbol{\mu}-\mathbf{C})$ solution attains vibrant lavender purple color. Its spectrum exhibits a convoluted, split band with a dominant absorbance at $536 \mathrm{~nm}$ and a small, yet well-resolved, peak at $665 \mathrm{~nm}$. Moreover, this form of the phthalocyaninate is characterized by significant absorbance in the near-infrared (NIR) range with a wide peak centered at $c a .1272 \mathrm{~nm}$ (Figure 3, curve 3 ). It should be noted that, as was evident from the $\mathrm{CV}$, these spectral changes are completely reversible upon application of reductive potential. These facts are a good premise for practical application for both color-changing applications, like electrochromic displays, and for NIR modulating devices.

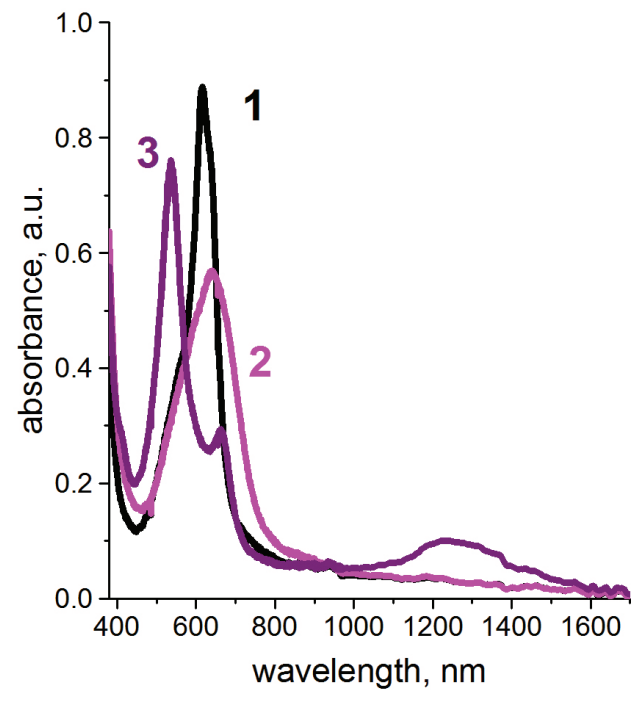

Figure 3. Visible-near-infrared range absorbance spectra of $\left[\mathbf{t B u} \mathbf{u}_{4} \mathbf{P c R u}\right]_{2}(\boldsymbol{\mu}-\mathbf{C})$ solution in (1) neutral form, and after (2) first and (3) second electrochemical oxidation.

However, it is quite obvious that any practical application requires creation of solid-state materials, as electrochromism in solution is not exactly convenient. In this regard, on the next stage of the present research, we studied electrochemical behavior of $\left[\mathbf{t B} \mathbf{u}_{4} \mathbf{P c R u}\right]_{2}(\boldsymbol{\mu}-\mathbf{C})$ thin films casted onto transparent FTO electrodes from dichloromethane solution of the complex. In solid form without application of any potential, obtained cast films (CF) exhibited the same teal-cyan coloring.

$\mathrm{CV}$ of thusly obtained samples also demonstrates two redox peaks corresponding to two subsequent electrochemical oxidations of the $\left[\mathbf{t B u} \mathbf{H}_{\mathbf{4}} \mathbf{P c R u}\right]_{2}(\boldsymbol{\mu}-\mathbf{C})$ in the film, as was previously observed in solution (Figure 4). However, halfwave potentials of these processes are slightly shifted, with $\mathrm{ox}_{1}$ occurring at $E_{1 / 2}$ of 0.51 and $\mathrm{ox}_{2}$ at $0.81 \mathrm{~V}$. Moreover, the shapes of the peaks, especially the latter, are markedly distorted, which is frequently observed in cast films, as they are characterized by chaotic molecular organization. Despite this, cyclic voltammetry showed perfect reversibility of both these redox processes and no deterioration of the observed current upon repeated cycling in the studied potential range from -0.4 to $1.4 \mathrm{~V}$.

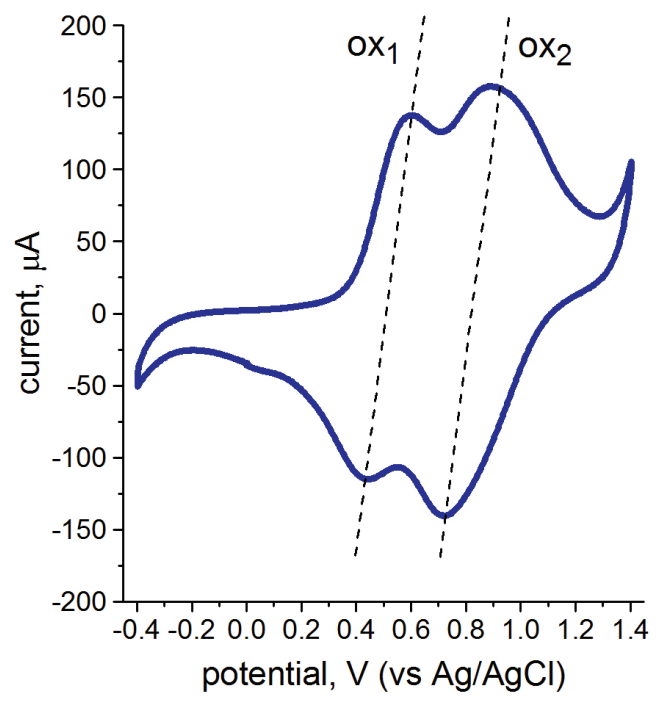

Figure 4. $\mathrm{CV}$ of $\left[\mathrm{tBu}_{4} \mathbf{P c R u}\right]_{2}(\boldsymbol{\mu}-\mathrm{C}) \mathrm{CF}$ in aqueous $0.1 \mathrm{M} \mathrm{NaClO}_{4}$. Dashed lines connect marked redox peaks on anodic and cathodic branches of the CV. Only the third cycle is shown for clarity.

Spectral changes observed upon electrochemical oxidation of $\left[\mathbf{t B u} \mathbf{u}_{4} \mathbf{P c R u}\right]_{2}(\boldsymbol{\mu}-\mathbf{C}) \mathrm{CF}$ coincide well with the ones recorded during the spectroelectrochemical experiment in solution. However, due to the fact that both redox peaks are closer together in this case, the spectrum of first oxidized form is not that clear, and bears some influence of the doubly oxidized form, as can be seen from Figure 5, where corresponding curve (curve 2 ) is obviously widened. The spectrum of the film after second oxidation (Figure 5, curve 3 ) resembles well the previously observed one, albeit with not so well resolved band ca. $665 \mathrm{~nm}$.

In case of cast films, changes of color are also consistent with the ones observed in solution. These changes are also completely reversible, and, due to $\left[\mathbf{t B} \mathbf{u}_{4} \mathbf{P c R u}\right]_{2}(\boldsymbol{\mu}-\mathbf{C})$ being confined to the electrode surface, occur much

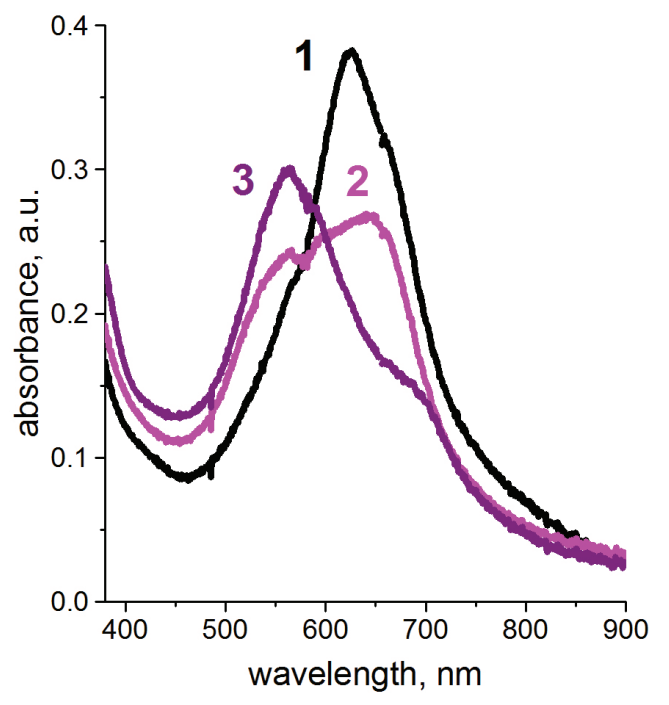

Figure 5. Visible range absorbance spectra of $\left[\mathbf{t B u}_{4} \mathbf{P c R u}\right]_{2}(\boldsymbol{\mu}-\mathbf{C})$ $\mathrm{CF}$ in (1) neutral form, and after (2) first and (3) second electrochemical oxidation. 
faster. However, aqueous electrolyte in this experiment became a limitation of the employed setup in a way that no NIR spectral changes could have been recorded due to absorbance of water (the electrolyte used) in this spectral region.

On the next stage of the present work, in order to study the electrochromic properties of $\left[\mathbf{t B u} \mathbf{u}_{4} \mathbf{P c R u}\right]_{2}(\boldsymbol{\mu}-\mathbf{C})$ in more organized systems, we employed the methods of Langmuir monolayers and Langmuir-Schaefer deposition.

It was shown that $\left[\mathbf{t B \mathbf { u } _ { \mathbf { 4 } }} \mathbf{P c R u}\right]_{\mathbf{2}}(\boldsymbol{\mu}-\mathbf{C})$ can indeed form true Langmuir monolayers on the surface of deionized water subphase. Surface pressure - mean molecular area isotherm for the monolayer of this compound is provided in Figure 6 . It can be seen that molecular area, at which the increase of surface pressure is observed amounts to $c a$. $300 \AA^{2}$. While this value is too small to correspond to face-on orientation of the studied molecule at the air/water interface, which should take up at least around $450 \AA^{2}$, the observed value probably signifies that at least partial stacking interaction between $\left[\mathbf{t B u} \mathbf{H}_{\mathbf{P}} \mathbf{P R u}\right]_{2}(\boldsymbol{\mu}-\mathbf{C})$ molecules in the monolayer takes place. Lateral compression of the monolayer leads to further reorientation of the molecules into edge-on position, with monolayer reaching most densely packed organization, which is evidenced by an upward bend on the isotherm at mean molecular area value around $100 \AA^{2}$.

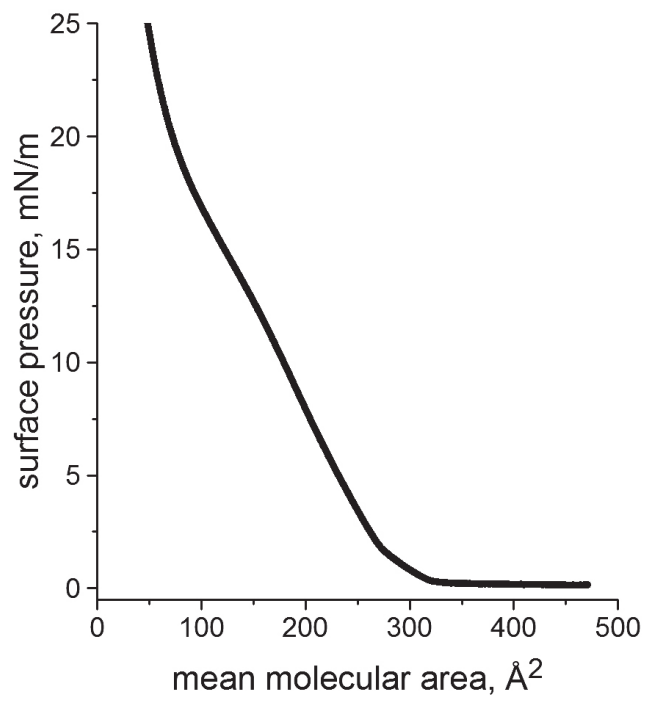

Figure 6. Compression isotherm of a $\left[\mathbf{t B u} \mathbf{u}_{4} \mathbf{P c R u}\right]_{2}(\boldsymbol{\mu}-\mathbf{C})$ Langmuir monolayer at the air/water interface.

Ultrathin films consisting of 14 monomolecular layers of $\left[\mathbf{t B u} \mathbf{H}_{\mathbf{4}} \mathbf{P c R u}\right]_{\mathbf{2}}(\boldsymbol{\mu}-\mathbf{C})$ were transferred onto FTO substrates via Langmuir-Schaefer (LS) deposition technique at surface pressure of $20 \mathrm{mN} / \mathrm{m}$, which corresponds to the abovementioned dense packing of the monolayer.

$\mathrm{CV}$ of the obtained film demonstrated electrochemical pattern similar to the one, observed for much thicker CF. Half-wave potentials of the two oxidation processes amounted to 0.53 and $0.83 \mathrm{~V}$ for $\mathrm{ox}_{1}$ and $\mathrm{ox}_{2}$, respectively (Figure 7). These values are extremely close to the potentials recorded for the cast film. This is due to the similarity of the studied systems, both being organic films on FTO electrodes in the same aqueous electrolyte. However, redox peaks of the LS film are much more resolved and their peakto-peak separation is smaller, which is explained by a higher degree of molecular organization of the LS film.

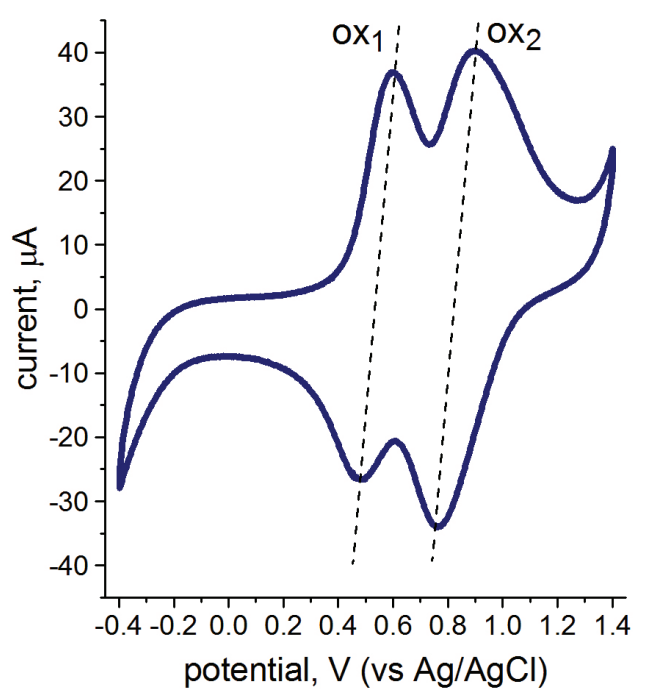

Figure 7. CV of a 14 layered Langmuir-Schaefer film of $\left[\mathbf{t B u} \mathbf{u}_{4} \mathbf{P c R u}\right]_{2}(\boldsymbol{\mu}-\mathbf{C})$ in aqueous $0.1 \mathrm{M} \mathrm{NaClO}_{4}$. Dashed lines connect marked redox peaks on anodic and cathodic branches of the CV. Only the third cycle is shown for clarity.

Spectral evolution observed upon oxidation of the $\left[\mathbf{t B u} \mathbf{P u}_{4} \mathbf{P c R u}\right]_{2}(\boldsymbol{\mu}-\mathbf{C})$ LS film (Figure 8), however, coincides well with the one recorded for thicker and unorganized CF. This, again, points towards similar nature of these samples. While electrochemical switching between the neutral and the oxidized states of the complex is much faster in the LS film, optical density achieved even at 14 layers is too low for practical applications in electrochromic devices. On the other hand, such fast action can find its uses in more intricate molecular switching and information storage devices.

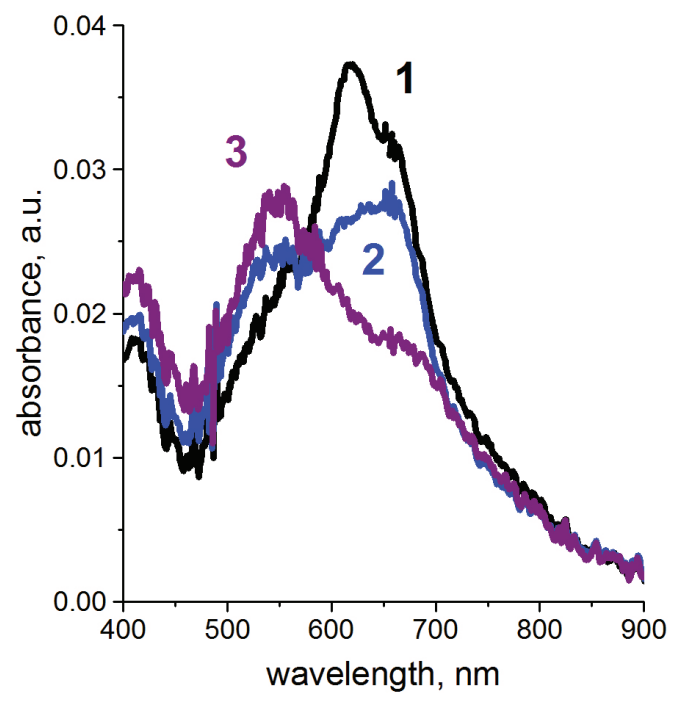

Figure 8. Visible range absorbance spectra of $\left[\mathbf{t B u}_{4} \mathbf{P c R u}\right]_{2}(\mu-\mathrm{C})$ LS film in (1) neutral form, and after (2) first and (3) second electrochemical oxidation. 

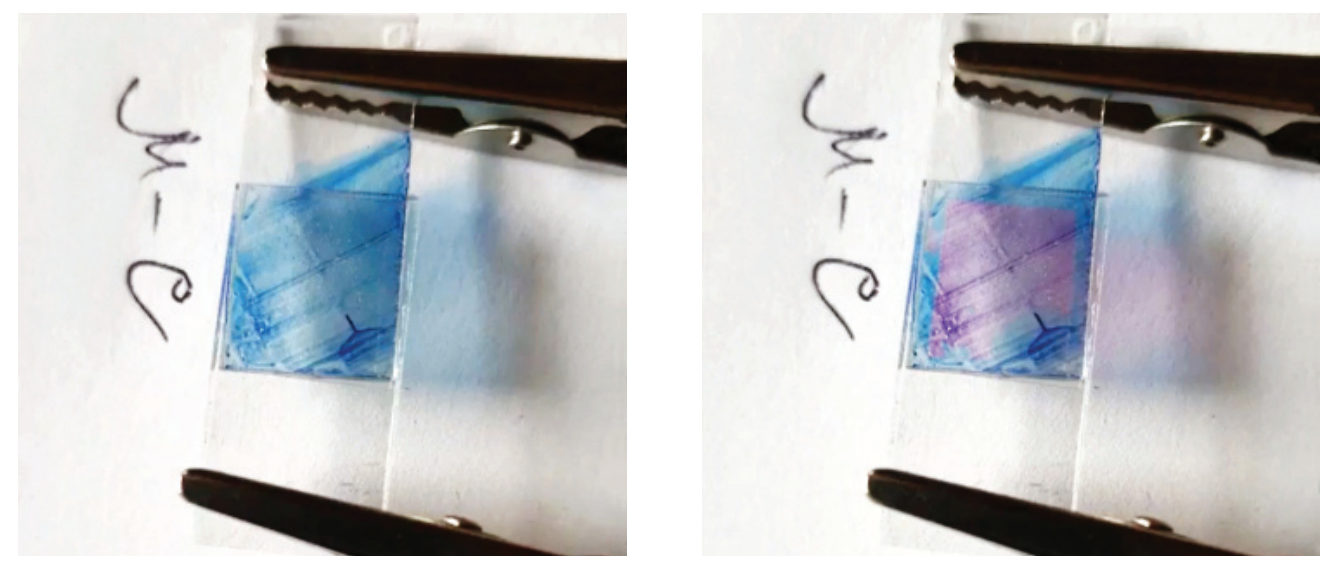

Figure 9. Still images of the electrochromic cell in neutral form (to the left) and two-electron oxidized state (to the right).

In order to demonstrate practical applicability of $\left[\mathbf{t B u} \mathbf{H}_{4} \mathbf{P c R u}\right]_{2}(\boldsymbol{\mu}-\mathbf{C})$ as cyan-purple solid-state electrochromes, we constructed a basic two-electrode electrochromic cell. The cell was made of two FTO electrodes, onto one of which a cast film of $\left[\mathbf{t B u} \mathbf{H}_{4} \mathbf{P c R u}\right]_{2}(\boldsymbol{\mu}-\mathbf{C})$ was deposited from its dichloromethane solution. A frame of double-sided tape with a $100 \mu \mathrm{m}$ thickness was used to both hold two electrodes together and contain aqueous $0.1 \mathrm{M}$ sodium perchlorate electrolyte between them.

Application of a $1.2 \mathrm{~V}$ potential (electrode with the film being positive terminal) to the cell leads to the color changes observed before, i.e. a shift from blue-teal to a vibrant purple color (as demonstrated in Figure 9). Colorimetric parameters of the cell in neutral and two-electron oxidized states in CIELAB color space for normal/normal (0/0) illuminating/viewing geometry for transmittance measurements ${ }^{[45]}$ are provided in the Table 1 . These parameters can be used to calculate color contrast values $\Delta E^{*}$ for thus assembled cells upon electrochromic switching as follows:

$$
\Delta E^{*}=\left[\left(L_{o x}^{*}-L_{n}^{*}\right)+\left(a_{o x}^{*}-a_{n}^{*}\right)+\left(b_{o x}^{*}-b_{n}^{*}\right)\right]^{1 / 2},
$$

where $\Delta E^{*}$ is the color contrast value, $\mathrm{L}^{*}, \mathrm{a}^{*}$, and $\mathrm{b}^{*}$ are CIE color space parameters of the cell in neutral and oxidized states, as denoted by the corresponding indices.

Obtained value for the studied two-electrode cell amounted to $\sim 11.2$, which signifies that the colors produced upon electrochemical switching are easily distinguishable. ${ }^{[46]}$

Table 1. Color of the two-electrode electrochromic device based on $\left[\mathbf{t B u} \mathbf{H}_{4} \mathbf{P c R u}\right]_{2}(\boldsymbol{\mu}-\mathbf{C}) \mathrm{CF}$ in neutral and electrochemically oxidized states, presented in CIELAB $\left(\mathrm{L}^{*} \mathrm{a}^{*} \mathrm{~b}\right)$ color space, and a representative color swatch.

\begin{tabular}{ccccc}
\hline \multicolumn{1}{c}{ State } & $\mathrm{L}^{*}$ & $\mathrm{a}^{*}$ & \multicolumn{1}{c}{$\mathrm{b}^{*}$} & Color swatch \\
\hline Neutral & 88.98 & -6.37 & -11.46 & \\
Oxidized & 88.57 & 4.71 & -9.93 & \\
\hline
\end{tabular}

While, according to spectroscopic measurements, complete conversion from neutral to oxidized state takes about a minute for a film with circa 1.1 units of optical den- sity at $620 \mathrm{~nm}$, the change of color is visible to the human eye in less than a second (see video in Supplementary Materials, https://macroheterocycles.isuct.ru/en/system/ files/mhc210234s_supp.mp4). This is evident on the kinetics of the $620 \mathrm{~nm}$ band absorbance changes upon application of oxidative and reductive potentials (Figure 10, curve 1). Exponential fitting of those shows that time of halfconversion at this band is $c a .1 .36 \mathrm{~s}$, which is quite good for electrochromic devices.

Moreover, construction of the cell ensured only a thin layer of aqueous electrolyte (around $100 \mu \mathrm{m}$ ), which, in its turn, allowed us to record absorbance in the near-infrared region. As was observed before, two-electron electrochemical oxidation of the $\left[\mathbf{t B u} \mathbf{u}_{\mathbf{4}} \mathbf{P c R u}\right]_{\mathbf{2}}(\boldsymbol{\mu}-\mathbf{C})$ leads to appearance of the wide absorbance band around $1300 \mathrm{~nm}$, and reduction, as expected, leads to its decrease. This spectral behavior is reproducible between the oxidation/reduction cycles (Figure 10), and it is as fast and reversible as the changes

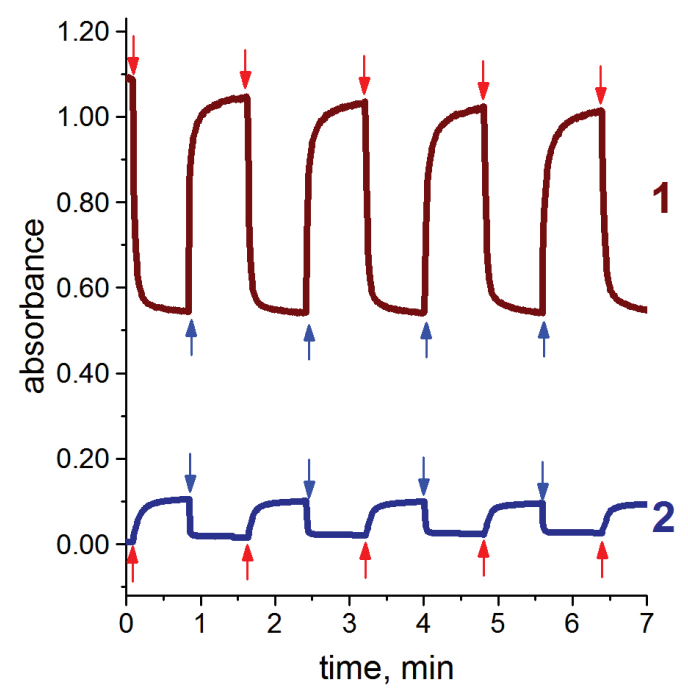

Figure 10. Changes of absorbance at the wavelengths of (1) 620 and (2) $1300 \mathrm{~nm}$ upon application of oxidative and reductive potentials (denoted by red and blue arrows, respectively) to the working electrode of the two-terminal electrochromic device based on a $\left[\mathbf{t B u} \mathbf{u}_{4} \mathbf{P c R u}\right]_{2}(\boldsymbol{\mu}-\mathbf{C})$ cast film. 
observed in the visible range. Modulation of absorbance in this spectral region can find practical applications in telecommunication devices that employ NIR signals.

\section{Conclusions}

A new $\mu$-carbido diruthenium(IV) tetra-tert-butyl phthalocyaninate was extensively characterized as a potential new material for electrochromic applications. It was shown that in solution, thin- and ultrathin Langmuir-Schaefer films it is capable of electrochemical switching between colors unusual for typical sandwich phthalocyaninates: teal-blue and lavender purple. Moreover, two-electron electrochemical oxidation of the complex leads to the appearance of a new absorbance band located in the near-infrared region $c a$. $1300 \mathrm{~nm}$. Modulation of the absorbance at this wavelength can be of use in optic telecommunication technologies. A basic two-electrode cell based on a thin film of the complex exhibited good color contrast, short switching time, and low operating voltage around $1.2 \mathrm{~V}$. Notably, this potential is achievable by household batteries, which also makes the studied system perspective in practical applications. All the studied systems demonstrated perfect reversibility of the color changes and NIR band modulation within tens of switching cycles.

Acknowledgements. The work was financially supported by the Ministry of Science and Higher Education of the Russian Federation ("Physicochemistry and Technology of Highly Effective Polyfunctional Materials Based on Macrocyclic Compounds", project no. 01201355 854). Some of the measurements were performed using equipment of CKP FMI IPCE RAS.

\section{References}

1. Kirin I.S., Moskalev P.N., Makashev Y.A. Russ. J. Inorg. Chem. 1965, 10, 1065-1066.

2. Weiss R., Fischer J. In: The Porphyrin Handbook, Vol 16, Elsevier, 2003. pp. 171-246.

3. Pushkarev V.E., Tomilova L.G., Nemykin V.N. Coord. Chem. Rev. 2016, 319, 110-179.

4. Koifman O.I., Ageeva T.A., Beletskaya I.P., Averin A.D., Yakushev A.A., Tomilova L.G., Dubinina T.V., Tsivadze A.Y., Gorbunova Y.G., Martynov A.G., Konarev D.V., Khasanov S.S., Lyubovskaya R.N., Lomova T.N., Korolev V.V., Zenkevich E.I., Blaudeck T., von Borczyskowski C., Zahn D.R.T., Mironov A.F., Bragina N.A., Ezhov A.V., Zhdanova K.A., Stuzhin P.A., Pakhomov G.L., Rusakova N.V., Semenishyn N.N., Smola S.S., Parfenyuk V.I., Vashurin A.S., Makarov S.V., Dereven'kov I.A., Mamardashvili N.Z., Kurtikyan T.S., Martirosyan G.G., Burmistrov V.A., Aleksandriiskii V.V., Novikov I.V., Pritmov D.A., Grin M.A., Suvorov N.V., Tsigankov A.A., Fedorov A.Y., Kuzmina N.S., Nyuchev A.V., Otvagin V.F., Kustov A.V., Belykh D.V., Berezin D.B., Solovieva A.B., Timashev P.S., Milaeva E.R., Gracheva Y.A., Dodokhova M.A., Safronenko A.V., Shpakovsky D.B., Syrbu S.A., Gubarev Y.A., Kiselev A.N., Koifman M.O., Lebedeva N.S., Yurina E.S. Macroheterocycles 2020, 13, 311-467.

5. Chen X., Qi D., Liu C., Wang H., Xie Z., Chen T.W., Chen S.M., Tseng T.W., Jiang J. RSC $A d v$. 2019, 10, 317-322.
6. Martynov A.G., Polovkova M.A., Berezhnoy G.S., Sinelshchikova A.A., Dolgushin F.M., Birin K.P., Kirakosyan G.A., Gorbunova Y.G., Tsivadze A.Y. Inorg. Chem. 2020, 59, 9424-9433.

7. Birin K.P., Poddubnaya A.I., Gorbunova Y.G., Tsivadze A.Y. Macroheterocycles 2017, 10, 514-515.

8. Bouvet M., Gaudillat P., Suisse J.-M. J. Porphyrins Phthalocyanines 2013, 17, 628-635.

9. Selektor S.L., Shokurov A.V., Arslanov V.V., Gorbunova Y.G., Raitman O.A., Isakova A.A., Birin K.P., Tsivadze A.Y. Russ. J. Electrochem. 2012, 48, 218-233.

10. Lindsey J.S., Bocian D.F. Acc. Chem. Res. 2011, 44, 638-650.

11. Martynov A.G., Safonova E.A., Tsivadze A.Y., Gorbunova Y.G. Coord. Chem. Rev. 2019, 387, 325-347.

12. Selektor S.L., Shokurov A.V., Raitman O.A., Sheinina L.S., Arslanov V.V., Birin K.P., Gorbunova Y.G., Tsivadze A.Y. Colloid J. 2012, 74, 334-345.

13. Shokurov A.V., Kutsybala D.S., Martynov A.G., Yagodin A.V., Gorbunova Y.G., Novikov D., Bakirov A.V., Shcherbina M.A., Chvalun S.N., Arslanov V.V. Selektor S. L. Macroheterocycles 2019, 12, 264-267.

14. Wang H., Wang B.W., Bian Y., Gao S., Jiang J. Coord. Chem. Rev. 2016, 306, 195-216.

15. Semenishyn N.N., Smola S.S., Rusakova N.V., Martynov A.G., Birin K.P., Gorbunova Y.G. Macroheterocycles 2018, 11, 262-268.

16. Smola S.S., Rusakova N.V., Kamalov G.L., Gorbunova Y.G., Tsivadze A.Y. Macroheterocycles 2017, 10, 268-272.

17. Corker G.A., Grant B., Clecak N. J. J. Electrochem. Soc. 1979, 126, 1339-1343.

18. Zhang J., Lu F., Huang H., Wang J., Yu H., Jiang J., Yan D., Wang Z. Synth. Met. 2005, 148, 123-126.

19. Rodríguez-Méndez M.L., Aroca R., DeSaja J.A. Chem. Mater. 1992, 4, 1017-1020.

20. Selektor S.L., Shokurov A.V., Revina A.A., Arslanov V.V., Gorbunova Y.G., Tsivadze A.Y. Macroheterocycles 2015, 8, 135-142.

21. Rodríguez-Méndez M.L., de Saja J.A. J. Porphyrins Phthalocyanines 2009, 13, 606-615.

22. Tang X., Liu Q., Wei C., Lv X., Jin Z., Chen Y., Jiang J. J. Rare Earths 2021, 39, 113-120.

23. Selektor S.L., Shokurov A.V. Prot. Met. 2015, 51, 171-203.

24. Selektor S.L., Sheinina L.S., Shokurov A.V., Raitman O.A., Arslanov V.V., Lapkina L.A., Gorbunova Y.G., Tsivadze A.Y. Prot. Met. 2011, 47, 447-456.

25. Tolbin A.Y., Pushkarev V.E., Tomilova L.G., Zefirov N.S. J. Porphyrins Phthalocyanines 2008, 12, 1187-1193.

26. Pushkarev V.E., Tolbin A.Y., Zhurkin F.E., Borisova N.E., Trashin S.A., Tomilova L.G., Zefirov N.S. Chem. Eur. J. 2012, 18, 9046-9055.

27. Krichevsky D.M., Zasedatelev A.V., Tolbin A.Y., Luchkin S.Y., Karpo A.B., Krasovskii V.I., Tomilova L.G. Thin Solid Films 2017, 642, 295-302.

28. Dubinina T.V., Belousov M.S., Maklakov S.S., Chernichkin V.I., Sedova M.V., Tafeenko V.A., Borisova N.E., Tomilova L.G. Dyes Pigm. 2019, 170, 107655.

29. Korostei Y.S., Pushkarev V.E., Tolbin A.Y., Dzuban A.V., Chernyak A.V., Konev D.V., Medvedeva T.O., Talantsev A.D., Sanina N.A., Tomilova L.G. Dyes Pigm. 2019, 170, 107648.

30. Tomilova L.G., Pushkarev V.E., Dubinina T.V., Tolbin A.Yu., Advances in the Synthesis and Study of the Properties of Phthalocyanines and Their Analogues, Moscow State University Publishing House, 2019 [Томилова Л.Г., Пушкарев В.Е., Дубинина Т.В., Толбин А.Ю. Достижения в синтезе и исследовании свойств фталоцианинов и их аналогов, Издательский дом МГУ, 2019].

31. Tomilova L.G., Gorbunova Y.G., Rodriguez-Mendez M.L., de Saja J.A. Mendeleev Commun. 1994, 4, 127-128. 
32. Gorbunova Y.G., Rodríguez-Méndez M.L., Souto J., Tomilova L.G., de Saja J.A. Chem. Mater. 1995, 7, 1443-1447.

33. Gorbunova Y.G., Rodríguez-Méndez M.L., Kalashnikova I.P., Tomilova L.G., de Saja J.A., Rodríguez-Morgade M.S. Langmuir 2001, 17, 5004-5010.

34. Ishikawa N. J. Porphyrins Phthalocyanines 2001, 5, 87-101.

35. May A., Majumdar P., Martynov A.G., Lapkina L.A., Troyanov S.I., Gorbunova Y.G., Tsivadze A.Y., Mack J., Nyokong T. J. Porphyrins Phthalocyanines 2020, 24, 589-601.

36. Rousseau R., Aroca R., Rodríguez-Méndez M.L. J. Mol. Struct. 1995, 356, 49-62.

37. Zhu P., Pan N., Ma C., Sun X., Arnold D.P., Jiang J. Eur. J. Inorg. Chem. 2004, 518-523.

38. Ercolani C. J. Porphyrins Phthalocyanines 2000, 4, 340-343.

39. Afanasiev P., Sorokin A.B. Acc. Chem. Res. 2016, 49, 583-593.
40. Kroitor A.P., Cailler L.P., Martynov A.G., Gorbunova Y.G., Tsivadze A.Y., Sorokin A.B. Dalton Trans. 2017, 46, 15651-15655.

41. Bottomley L.A., Gorce J.N., Goedken V.L., Ercolani C. Inorg. Chem. 1985, 24, 3733-3737.

42. Şahin Z., Meunier-Prest R., Dumoulin F., Ișci Ü., Bouvet M. Inorg. Chem. 2020, 59, 1057-1067.

43. Kroitor A.P., Martynov A.G., Gorbunova Y.G., Tsivadze A.Y., Sorokin A.B. Eur. J. Inorg. Chem. 2019, 2019, 1923-1931.

44. Kienast A., Galich L., Murray K.S., Moubaraki B., Lazarev G., Cashion J.D., Homborg H. J. Porphyrins Phthalocyanines 1997, 1, 141-157.

45. Markus R.T. The Measurement of Color. In: Color for Science, Art and Technology (Nassau K., Ed.), 1998. 490 p.

46. Mahy M., Van Eycken L., Oosterlinck A. Color Res. Appl. 1994, 19, 105-121. 